\title{
PENGARUH KONSENTRASI NATRIUM METABISULFIT DAN LAMA PERENDAMAN TERHADAP KARAKTERISTIK BUBUK BUNGA KENIKIR (Tagetes erecta L.)
}

\author{
The Effect of Sodium Metabisulfite Concentration and Soaking Time on The Characteristics \\ of Marigold Flower Powder (Tagetes erecta L.)
}

\author{
Komang Adi Darmawan, Ni Made Wartini *, Luh Putu Wrasiati \\ PS Teknologi Industri Pertanian, Fakultas Teknologi Pertanian, Universitas Udayana, Kampus Bukit \\ Jimbaran, Badung, Kode pos : 80361; Telp/Fax : (0361) 701801.
}

Diterima 13 November 2018 / Disetujui 08 Januari 2019

\begin{abstract}
Marigold powder can be used as natural orange dyes extract of marigold powder contain $\beta$-carotene. The aim of this research was to investigate the effect of sodium metabisulfite $\left(\mathrm{Na}_{2} \mathrm{~S}_{2} \mathrm{O}_{5}\right)$ concentration and soaking time on the characteristics of marigold flower powder and determine the best treatment of the concentration of sodium metabisulphite $\left(\mathrm{Na}_{2} \mathrm{~S}_{2} \mathrm{O}_{5}\right)$ and soaking time to produce powdered marigold flowers. This research used factorial randomized block design with 2 factor experiments. The first factor is the concentration of sodium metabisulfite $\left(\mathrm{Na}_{2} \mathrm{~S}_{2} \mathrm{O}_{5}\right)$ which consists of 3 levels: 2000, 2500, and 3000 ppm. The second factor is the soaking time which consists of 3 levels: 10, 20, and 30 minutes. The results of research showed that the treatment of sodium metabisulfite $\left(\mathrm{Na}_{2} \mathrm{~S}_{2} \mathrm{O}_{5}\right)$ concentration take effect on water content, total carotenoid levels, brightness $\left(L^{*}\right)$, yellowish level $\left(b^{*}\right)$, and sulfite residue levels, but no effect to the level of redness ( $\left.a^{*}\right)$. The treatment of soaking time take effect on the levels of sulfite residues but no effect on water content, total carotenoid levels, brightness level ( $\left.L^{*}\right)$, yellowish level $\left(b^{*}\right)$, and redness level $\left(a^{*}\right)$. Soaking treatment in sodium metabisulfite $\left(\mathrm{Na}_{2} \mathrm{~S}_{2} \mathrm{O}_{5}\right)$ solution with a concentration of 2500 ppm and soaking time of 10 minutes, is the best treatment to produce marigold flower powder with the characteristics of water content 11,40\%, total carotenoid levels of $18.91 \%$, brightness level ( $\left.L^{*}\right) 44.19$, redness level ( $\left.a^{*}\right) 63.80$, yellowish level ( $\left.b^{*}\right) 56.86$, and sulfite residue levels of $182.40 \mathrm{ppm}$.
\end{abstract}

Keywords : Tagetes erecta L, sodium metabisulfite, carotenoid, color.

\section{ABSTRAK}

Bubuk kenikir dapat digunakan sebagai ekstrak pewarna oranye alami yang mengandung $\beta$-karoten. Tujuan dari penelitian ini adalah untuk mengetahui pengaruh konsentrasi natrium metabisulfit $\left(\mathrm{Na}_{2} \mathrm{~S}_{2} \mathrm{O}_{5}\right)$ dan lama perendaman terhadap karakteristik bubuk bunga kenikir dan menentukan perlakuan terbaik dari konsentrasi natrium metabisulfit $\left(\mathrm{Na}_{2} \mathrm{~S}_{2} \mathrm{O}_{5}\right)$ dan lama perendaman untuk menghasilkan bubuk bunga kenikir. Penelitian ini menggunakan rancangan acak kelompok faktorial 2 faktor. Faktor pertama adalah konsentrasi natrium metabisulfit $\left(\mathrm{Na}_{2} \mathrm{~S}_{2} \mathrm{O}_{5}\right)$ yang terdiri dari 3 taraf: 2000, 2500, dan 3000 ppm. Faktor kedua adalah lama perendaman yang terdiri dari 3 taraf: 10, 20, dan 30 menit. Hasil penelitian menunjukkan bahwa perlakuan konsentrasi natrium metabisulfit $\left(\mathrm{Na}_{2} \mathrm{~S}_{2} \mathrm{O}_{5}\right)$ memiliki pengaruh terhadap kadar air, kadar total karotenoid , tingkat kecerahan ( $\left.\mathrm{L}^{*}\right)$, tingkat kekuningan $\left(\mathrm{b}^{*}\right)$, dan kadar residu

*Korespondensi Penulis:

Email : md_wartini@unud.ac.id 
sulfit, tetapi tidak berpengaruh terhadap tingkat kemerahan $\left(a^{*}\right)$. Perlakuan lama perendaman ber pengaruh pada kadar residu sulfit tetapi tidak berpengaruh terhadap kadar air, kadar total karotenoid, tingkat kecerahan $\left(\mathrm{L}^{*}\right)$, tingkat kekuningan $\left(\mathrm{b}^{*}\right)$, dan tingkat kemerahan $\left(\mathrm{a}^{*}\right)$. Perlakuan perendaman dalam larutan natrium metabisulfit $\left(\mathrm{Na}_{2} \mathrm{~S}_{2} \mathrm{O}_{5}\right)$ dengan konsentrasi $2500 \mathrm{ppm}$ dan lama perendaman 10 menit merupakan perlakuan terbaik untuk menghasilkan bubuk bunga kenikir dengan karakteristik kadar air 11,40\%, kadar total karotenoid 18,91\%, tingkat kecerahan $\left(\mathrm{L}^{*}\right) 44,19$, tingkat kemerahan $\left(\mathrm{a}^{*}\right)$ 63,80, tingkat kekuningan (b*) 56,86, dan kadar residu sulfit 182.40 ppm.

Kata kunci : Tagetes erecta L, natrium metabisulfit, karotenoid, warna.

\section{PENDAHULUAN}

Bunga kenikir merupakan tumbuhan hias yang biasanya tumbuh di perkebunan atau di taman. Di masyarakat dikenal ada dua jenis tanaman kenikir, yaitukenikir lokal (Cosmos sulphureus) dan kenikir marigold (Tagetes erecta L.) (Arini et al., 2015). Di Pulau Bali bunga kenikir jenis marigold banyak digunakan oleh masyarakat untuk sarana upacara keagamaan. Bunga kenikir memiliki mahkota bunga yang berwarna kuning sampai oranye, warna kuning ini disebabkan oleh dua pigmen utama yaitu dari golongan karotenoid yang memberi warna kuning sampai merah dan dari golongan flavonoid yang memberi warna kuning. Pigmen yang terdapat pada bunga kenikir marigold digunakan untuk pewarna makanan bagi manusia maupun ternak (Priyanka et al., 2013). Ekstrak bunga kenikir mengandung sekitar 27\% pigmen karotenoid atau khusus untuk mahkota kenikir mengandung karotenoid sekitar 200 kali lebih besar dari karotenoid yang dikandung oleh jagung (Vasudevan et al., 1997).

Pewarna dari bunga kenikir didapat melalui proses ekstraksi. Penelitian mengenai ekstraksi pewarna dari bunga kenikir telah dilakukan sebelumnya oleh Aristyanti et tidak dapat mengkatalis oksidasi senyawa fenolik penyebab browning (Akolo dan Aziz., 2018). Selain dapat mengurangi penurunan kadar karotenoid, perendaman dengan natrium metabisulfit juga dapat mempercepat penurunan kadar air saat pengeringan (Herudiyanto et al., 2007). Pada penelitian yang dilakukan oleh Prabasini et al.(2017). Sebelum proses ekstraksi dilakukan, bahan biasanya dikeringkan kemudian dihancurkan sampai menjadi bubuk. Hal ini dilakukan untuk mengurangi kadar air supaya bahan tidak mudah rusak, dapat disimpan sebelum bahan diekstraksi, dan penurunan kadar air juga akan mempermudah kelarutan bahan pada pelarut sehingga proses ekstraksi bisa dilakukan lebih singkat. Selain itu, pengecilan ukuran partikel bahan berfungsi untuk menambah luas permukaan bahan supaya kontak bahan dengan pelarut lebih optimal.

Selama pengeringan bunga kenikir, kemungkinan terjadi pencoklatan atau pengurangan intensitas warna kuning (kadar karotenoid) akibat pengaruh panas. Oleh sebab itu perlu dilakukan perlakuan pendahuluan sebelum bahan dikeringkan. Perlakuan pendahuluan dapat berupa perendaman dengan larutan asam atau basa seperti $\mathrm{Ca}(\mathrm{OH})_{2}$, natrium bisulfit, natrium metabisulfit, asam askorbat dan asam lainnya. Natrium metabisulfit $\left(\mathrm{Na}_{2} \mathrm{~S}_{2} \mathrm{O}_{5}\right)$ dipilih sebagai bahan perendam karena dapat melindungi bahan dari oksidasi yang menyebabkan rekasi pencoklatan (Padmaningrum et al., 2009). Sulfit akan mereduksi ikatan disulfida pada enzim, sehingga enzim

al.(2013) mengenai perendaman labu kuning dengan natrium metabisulfit diperoleh perlakuan dengan konsentrasi 0,25\% (2500 ppm) dan lama perendaman 20 menit yang menghasilkan bubuk labu kuning terbaik.

Penelitan ini menggunakan konsentrasi natrium metabisulfit yaitu 2000, 2500, dan 3000 ppm dengan lama perendaman yang 
digunakan adalah 10, 20, dan 30 menit sebagai perlakuan. Penelitian ini bertujuan untuk mengetahui pengaruh konsentrasi natrium metabisulfit dan lama perendaman terhadap karakteristik bubuk bunga kenikir dan menentukan konsentrasi natrium metabisulfit dan lama perendaman terbaik untuk menghasilkan bubuk bunga kenikir.

\section{METODE PENELITIAN}

\section{Tempat dan Waktu Penelitian}

Penelitian ini dilakukan di
Laboratorium Rekayasa Proses dan
Pengendalian Mutu, Laboratorium
Pengolahan Pangan, dan Laboratorium
Analisis Pangan. Fakultas Teknologi
Pertanian Universitas Udayana. Penelitian ini
dilakukan pada Juli sampai September 2018.

\section{Bahan dan Alat}

Bahan utama pada penelitian ini yaitu bunga kenikir marigold (Tagetes erecta L.) yang diperoleh dari Desa Tua, Kecamatan Marga, Kabupaten Tabanan, Provinsi Bali, dengan kriteria bunga mekar berwarna oranye kekuningan dan diameter bunga 6-8 $\mathrm{cm}$. Sedangkan bahan-bahan kimia yang digunakan untuk proses yaitu akuades, bahan perendam yaitu natrium metabisulfit, dan bahan kimia untuk analisis yang bersifat pro analysis (pa) (E-Merck) yaitu petroleum benzena, aseton, $\mathrm{Na}_{2} \mathrm{SO}_{4}$ anhidrat, bubuk $\beta$ karoten, $\mathrm{NaOH}, \mathrm{HCl}$, formaldehid (39\%), iodin $0,02 \mathrm{~N}$ dan indikator amilum.

Peralatan yang digunakan pada penelitian yaitu oven (Blue M), gelas ukur (Herma, Iwaki), blender (Philips), ayakan 60 mesh (Retsch), aluminium foil, pipet tetes, $\mathrm{pH}$ meter. Peralatan yang digunakan untuk analisis terdiri dari timbangan analitik (SHIMADZU-ATY224), Erlenmeyer (Duran), gelas beaker (Pyrex, Iwaki), penjepit, oven (Cole-Parmer, StableTemp), desikator (Duran), tabung reaksi (Iwaki), kertas saring kasar, pipet volume (Iwaki), corong pisah (Pyrex), color reader (Accuprobe HH-06), spektrofotometer (Genesys 10S UV-VIS), vortex (Barnstead Thermolyne Maxi Mix II), dan mikro buret (EM-hirschmann).

\section{Rancangan Percobaan}

Percobaan ini merupakan percobaan faktorial 2 faktor menggunakan Rancangan Acak Kelompok (RAK). Faktor I yaitu konsentrasi natrium metabisulfit $(\mathrm{K})$ terdiri atas 3 taraf yaitu: $\mathrm{K} 1=2000$ ppm, K2 $=2500$ ppm, K3 = 3000 ppm. Faktor II yaitu lama perendaman $(\mathrm{T})$ terdiri atas 3 taraf yaitu: $\mathrm{T} 1$ $=10$ menit, $\mathrm{T} 2=20$ menit, $\mathrm{T} 3=30$ menit. Dari 2 faktor di atas diperoleh 9 kombinasi perlakuan, masing-masing perlakuan dilakukan 2 kali berdasarkan waktu pengerjaanya sehingga diperoleh 18 satuan percobaan. Data obyektif yang diperoleh diuji dengan analisis keragaman dan apabila perlakuan berpengaruh terhadap variabel yang diamati, maka dilanjutkan dengan uji lanjut Tukey 5\% menggunakan software minitab 16. Perlakuan terbaik ditentukan dari perlakuan yang menghasilkan kadar karotenoid tertinggi.

\section{Pelaksanaan Penelitian}

Mahkota bunga kenikir marigold (Tagetes erecta L.) disortasi untuk memilih warna mahkota bunga yang seragam kemudian dipisahkan mahkota bunga dari dasar bunganya. Pembuatan larutan natrium metabisulfit dilakukan dengan melarutkan natrium metabisulfit dalam air sehingga terbentuk larutan dengan konsentrasi sesuai perlakuan yaitu 2000, 2500, dan 3000 ppm. Dilakukan pengukuran $\mathrm{pH}$ pada setiap larutan. Masing-masing $\mathrm{pH}$ larutan yaitu: konsentrasi $2000 \mathrm{ppm}=5,2,2500 \mathrm{ppm}=5,0$, dan $3000 \mathrm{ppm}=4,9$. Mahkota bunga direndam ke dalam larutan natrium metabisulfit pada perbandingan bahan dengan larutan yaitu $1: 3$ dan perendaman dilakukan selama 10, 20, dan 30 menit. 
Setelah direndam mahkota bunga ditiriskan kemudian dikeringkan menggunakan oven pada suhu $50 \pm 5^{\circ} \mathrm{C}$ sampai kering dan mudah dihancurkan (kadar air sekitar 10\%). Bunga kenikir kering kemudian dihancurkan dengan blender dan diayak dengan ayakan 60 mesh.

\section{Variabel yang Diamati}

Variabel yang diamati pada bubuk bunga kenikir adalah: kadar total karoten (Muchtadi, 1989), intensitas warna sistem $L^{*}, a^{*}, b^{*}$ (Weaver, 1996), residu sulfit metode titrasi (Ranganna,1997) dan kadar air (Sudarmadji et al., 1997).

\section{HASIL DAN PEMBAHASAN}

\section{Kadar Air}

Hasil analisis keragaman menunjukkan bahwa perlakuan konsentrasi natrium metabisufit berpengaruh sangat nyata $(\mathrm{P} \leq 0,01)$, sedangkan perlakuan lama perendaman dan interaksi kedua perlakuan berpengaruh tidak nyata $(\mathrm{P}>0,05)$ terhadap kadar air bubuk bunga kenikir marigold. Nilai rata-rata dari kadar air dapat dilihat pada Tabel 1.

Tabel 1 menunjukkan bahwa perlakuan konsentrasi 2000 ppm menghasilkan kadar air terbesar pada bubuk bunga kenikir. Kadar air pada perlakuan konsentrasi natrium metabisulfit tidak berbeda nyata, tetapi cenderung menurun. Semakin tinggi konsentrasi natrium metabisulfit maka kadar air semakin menurun. Semakin rendah kadar air pada proses pengeringan dengan suhu dan waktu yang sama menunjukan bahwa bahan semakin cepat kering. Hal ini dikarenakan perendaman dengan natrium metabisulfit dapat merusak jaringan yang menyebabkan sel terbuka sehingga air dalam bahan mudah teruapkan. Hasil ini didukung oleh penelitian Prabasini et al. (2013) mengenai perendaman labu kuning dengan natrium metabisulfit menunjukkan bahwa semakin tinggi konsentrasi natrium metabisulfit maka kadar air semakin rendah. Pada perlakuan lama perendaman rata-rata kadar air cenderung menurun ketika lama perendaman ditingkatkan. Hali ini terjadi karena semakin lama perendaman maka jaringan bahan semakin rusak sehingga mempermudah penguapan pada saat pengeringan.

\section{Kadar Total Karotenoid}

Hasil analisis keragaman menunjukkan bahwa perlakuan konsentrasi natrium metabisufit berpengaruh sangat nyata $(\mathrm{P} \leq 0,01)$, sedangkan perlakuan lama perendaman dan interaksi kedua perlakuan berpengaruh tidak nyata $(\mathrm{P}>0,05)$ terhadap kadar total karotenoid. Nilai rata-rata dari kadar total karotenoid dapat dilihat pada Tabel 2.

Tabel 2 menunjukkan bahwa rata-rata kadar karotenoid tertinggi dihasilkan oleh bubuk bunga kenikir yang direndam dengan larutan natrium metabisulfit $\left(\mathrm{Na}_{2} \mathrm{~S}_{2} \mathrm{O}_{5}\right)$ konsentrasi 2500 ppm. Hal tersebut membuktikan bahwa perendaman dalam natrium metabisulfit $\left(\mathrm{Na}_{2} \mathrm{~S}_{2} \mathrm{O}_{5}\right)$ dengan konsentrasi 2500 ppm lebih efektif untuk mencegah pencoklatan karena natrium metabisulfit bersifat reduktif. Oksidasi akan terjadi pada larutan natrium metabisulfit sehingga dapat mencegah proses pencoklatan pada bunga dan dapat mempertahankan karotenoid. Sulfit akan mereduksi ikatan disulfida pada enzim, sehingga enzim tidak dapat mengkatalis oksidasi senyawa fenolik penyebab browning (Akolo dan Aziz., 2018). Oksigen yang membantu reaksi pencoklatan diikat oleh radikal SO, sehingga reaksi pencoklatan dapat diturunkan kecepatannya (Tan et al., 2015).

Ketika konsentrasi ditingkatkan menjadi 3000 ppm kandungan karotenoidnya menjadi turun. Hal ini disebabkan oleh semakin tinggi konsentrasi natrium metabisulfit maka sel akan semakin rusak sehingga karoten teroksidasi. Hasil ini didukung oleh penelitian Prabasini et al. 
(2013) mengenai perendaman labu kuning dengan natrium metabisulfit menunjukkan bahwa perlakuan dengan konsentrasi $0,25 \%$ (2500 ppm) dapat mempertahankan kadar karoten lebih baik dibandingkan dengan perlakuan tanpa direndam dan direndam dengan larutan natrium metabisulfit konsentrasi $0,30 \%$ (3000 ppm). Perlakuan lama perendaman berpengaruh tidak nyata, namun rata-rata kadar karotenoid cenderung menurun seiring bertambahnya waktu perendaman. Hal ini terjadi karena semakin lama perendaman, maka sel pada bunga akan semakin rusak sehingga mudah teroksidasi yang menyebabkan kandungan karotenoid menjadi turun

Tabel 1. Nilai rata-rata kadar air (\%) pada perlakuan konsentrasi natrium metabisulfit dan lama perendaman.

\begin{tabular}{ccccc}
\hline Konsentrasi Natrium & \multicolumn{3}{c}{ Lama Perendaman (menit) } & Rata-rata \\
\cline { 2 - 4 } Metabisulfit $(\mathrm{ppm})$ & 10 & 20 & 30 & \\
\hline 2000 & 14,30 & 12,15 & 11,15 & $12,53 \pm 1,61^{\mathrm{a}}$ \\
2500 & 11,40 & 11,15 & 10,40 & $10,98 \pm 0,52^{\mathrm{ab}}$ \\
3000 & 10,15 & 10,35 & 9,80 & $10,10 \pm 0,28^{\mathrm{b}}$ \\
\hline Rata-rata & $11,95 \pm 2,13^{\text {a }}$ & $11,22 \pm 0,90^{\text {a }}$ & $10,45 \pm 0,68^{\text {a }}$ &
\end{tabular}

Keterangan : Huruf yang berbeda di belakang nilai rata-rata pada baris atau kolom yang sama menunjukkan adanya perbedaan yang nyata. Data merupakan rata-rata dari dua kelompok percobaan.

Tabel 2. Nilai rata-rata kadar total karotenoid (\% bk) pada perlakuan konsentrasi natrium metabisulfit dan lama perendaman.

\begin{tabular}{ccccc}
\hline $\begin{array}{c}\text { Konsentrasi Natrium } \\
\text { Metabisulfit }(\mathrm{ppm})\end{array}$ & \multicolumn{3}{c}{ Lama Perendaman (menit) } & Rata-rata \\
\cline { 2 - 4 } & 10 & 20 & 30 & \\
\hline 2000 & 14,51 & 14,63 & 14,34 & $14.49 \pm 0,15^{\mathrm{b}}$ \\
2500 & 18,91 & 18,04 & 17,62 & $18,19 \pm 0,66^{\mathrm{a}}$ \\
3000 & 15,34 & 15,65 & 15,76 & $15,58 \pm 0,22^{\mathrm{b}}$ \\
\hline
\end{tabular}

\begin{tabular}{ccc}
\hline Rata-rata $16,25 \pm 2,34^{\text {a }}$ & $16,11 \pm 1,75^{\text {a }}$ & $15,90 \pm 1,64^{\text {a }}$ \\
Keterangan: & Huruf yang berbeda di belakang nilai rata-rata pada baris atau kolom yang sama menunjukkan adanya
\end{tabular}
perbedaan yang nyata . Data merupakan rata-rata dari dua kelompok percobaan.

\section{Tingkat kecerahan $\left(\mathrm{L}^{*}\right)$}

Hasil analisis keragaman menunjukkan bahwa perlakuan konsentrasi natrium metabisufit berpengaruh sangat nyata $(\mathrm{P} \leq 0,01)$, sedangkan perlakuan lama perendaman dan interaksi kedua perlakuan berpengaruh tidak nyata $(\mathrm{P}>0,05)$ terhadap tingkat kecerahan $\left(\mathrm{L}^{*}\right)$ bubuk bunga kenikir marigold. Nilai $\left(\mathrm{L}^{*}\right)$ menyatakan tingkat gelap sampai terang dengan kisaran $0-100$. Nilai rata-rata dari tingkat kecerahan $\left(\mathrm{L}^{*}\right)$ dapat dilihat pada Tabel 3.

Tabel 3 menunjukkan bahwa tingkat kecerahan semua perlakuan lama perendaman berpengaruh tidak nyata, tetapi memiliki kecenderungan meningkat seiring penambahan waktu perendamannya. Hal ini diduga karena semakin lama perendaman maka sel akan semakin rusak sehingga karoten menurun yang menyebabkan warna bubuk semakin cerah. Perlakuan konsentrasi natrium metabisulfit berpengaruh nyata terhadap tingkat kecerahan (L*). Bubuk bunga kenikir yang dihasilkan dari perlakuan perendaman dengan konsentrasi 3000 ppm memiliki tingkat kecerahan tertinggi. Hal ini disebabkan oleh semakin tinggi konsentrasi natrium metabisulfit maka sel akan semakin rusak sehingga kadar karoten menurun. Penurunan kadar karotenoid yang dihasilkan pada konsentrasi 3000 ppm menyebabkan tingkat kecerahan menjadi semakin tinggi. Semakin tinggi tingkat kecerahan berarti kandungan pigmen semakin rendah (Khuluq 
et al., 2007).

Hasil ini didukung oleh penelitian Slamet (2010) tentang perlakuan pendahuluan pembuatan tepung ganyong menunjukkan bahwa tepung ganyong yang dihasilkan dengan diberi perlakuan pendahuluan perendaman dalam larutan natrium metabisulfit memiliki warna yang lebih baik (cerah).

Tabel 3. Nilai rata-rata tingkat kecerahan $\left(\mathrm{L}^{*}\right)$ pada perlakuan konsentrasi natrium metabisulfit dan lama perendaman.

\begin{tabular}{ccccc}
\hline Konsentrasi Natrium & \multicolumn{3}{c}{ Lama Perendaman (menit) } & Rata-rata \\
\cline { 2 - 4 } Metabisulfit (ppm) & 10 & 20 & 30 & \\
\hline 2000 & 43,40 & 43,89 & 44.84 & $44,04 \pm 0,73^{\mathrm{b}}$ \\
2500 & 44,19 & 45,65 & 46,31 & $45,38 \pm 1,09^{\mathrm{ab}}$ \\
3000 & 45,63 & 46,54 & 47,10 & $46,42 \pm 0,74^{\mathrm{a}}$ \\
\hline Rata-rata & $44,40 \pm 1,13^{\mathrm{a}}$ & $45,36 \pm 1,35^{\mathrm{a}}$ & $46,08 \pm 1,14^{\mathrm{a}}$ & \\
\hline
\end{tabular}

Keterangan: Huruf yang berbeda di belakang nilai rata-rata pada baris atau kolom yang sama menunjukkan adanya perbedaan yang nyata . Data merupakan rata-rata dari dua kelompok percobaan.

\section{Tingkat kemerahan $\left(a^{*}\right)$}

Hasil analisis keragaman menunjukkan bahwa faktor perlakuan konsentrasi natrium metabisufit, perlakuan lama perendaman dan interaksi kedua perlakuan berpengaruh tidak nyata $(\mathrm{P}>0,05)$ terhadap tingkat kemerahan (a*) bubuk bunga kenikir marigold. Nilai (a*) menyatakan tingkat warna hijau sampai merah dengan kisaran -100 sampai +100 . Nilai rata-rata dari tingkat kemerahan $\left(\mathrm{L}^{*}\right)$ dapat dilihat pada Tabel 4 .

Tabel 4. Nilai rata-rata tingkat kemerahan $\left(\mathrm{a}^{*}\right)$ pada perlakuan konsentrasi natrium metabisulfit dan lama perendaman.

\begin{tabular}{ccccc}
\hline Konsentrasi Natrium & \multicolumn{3}{c}{ Lama Perendaman (menit) } & Rata-rata \\
\cline { 2 - 5 } Metabisulfit (ppm) & 10 & 20 & 30 & \\
\hline 2000 & 63,99 & 63,14 & 58,36 & $61,83 \pm 3,04^{\text {a }}$ \\
2500 & 63,80 & 61,96 & 57,15 & $60,97 \pm 3,43^{\text {a }}$ \\
3000 & 61,58 & 60,05 & 56,36 & $59,33 \pm 2,68^{\text {a }}$ \\
\hline
\end{tabular}

\begin{tabular}{cccc}
\hline Rata-rata & $63,13 \pm 1,34^{\text {a }}$ & $61,72 \pm 1,56^{\text {a }}$ & $57,29 \pm 1,01^{\text {a }}$ \\
\hline Keterangan : Huruf yang berbeda di belakang nilai rata-rata pada baris atau kolom yang sama menunjukkan adanya
\end{tabular}
perbedaan yang nyata Data merupakan rata-rata dari dua kelompok percobaan.

Tabel 4 menunjukkan bahwa rata-rata tingkat kemerahan $\left(a^{*}\right)$ pada semua perlakuan berbeda tidak nyata, akan tetapi tingkat kemerahannya cenderung menurun seiring penambahan konsentrasi natrium metabisulfit. Tingkat kemerahan juga menurun seiring peningkatan lama waktu perendaman. Hal ini berkaitan dengan tingkat kecerahan yang semakin tinggi seiring penambahan konsentrasi dan lama perendaman. Tingkat kemerahan menurun sehingga tingkat kecerahan meningkat. Semakin tinggi kadar karotenoid maka semakin tinggi tingkat kemerahan (Satriyanto et al., 2012).

\section{Tingkat kekuningan (b*)}

Hasil analisis keragaman menunjukkan bahwa perlakuan konsentrasi natrium metabisufit berpengaruh sangat nyata $(\mathrm{P} \leq 0,01)$, sedangkan perlakuan lama perendaman dan interaksi kedua perlakuan berpengaruh tidak nyata $(\mathrm{P}>0,05)$ terhadap tingkat kekuningan $\left(b^{*}\right)$ bubuk bunga kenikir marigold. Nilai $\left(b^{*}\right)$ menyatakan tingkat warna biru sampai kuning dengan kisaran - 
100 sampai +100 . Nilai rata-rata tingkat kekuningan ( $\left.b^{*}\right)$ dapat dilihat pada Tabel 5.

Tabel 5 menunjukkan bahwa tingkat kekuningan tertinggi diperoleh dari bubuk bunga kenikir dengan perlakuan konsentrasi natrium metabisulfit $2500 \mathrm{ppm}$. Ketika konsentrasi ditingkatkan menjadi 3000 ppm tingkat kekuningan menjadi menurun. Hal ini menunjukkan bahwa jika kadar karotenoid tinggi maka tingkat kekuningan juga tinggi.
Karotenoid merupakan pigmen alami berwarna merah, kuning atau oranye (Gross, 1991).

Hasil ini didukung oleh penelitian Aristyanti et al. (2017) tentang ekstraksi karotenoid dari bunga kenikir yang menunjukkan semakin tinggi kadar karotenoid maka tingkat kekuningan sampai kemerahan juga semakin tinggi.

Tabel 5. Nilai rata-rata tingkat kekuningan $\left(b^{*}\right)$ pada perlakuan konsentrasi natrium metabisulfit dan lama perendaman.

\begin{tabular}{|c|c|c|c|c|}
\hline \multirow{2}{*}{$\begin{array}{l}\text { Konsentrasi Natrium } \\
\text { Metabisulfit (ppm) }\end{array}$} & \multicolumn{3}{|c|}{ Lama Perendaman (menit) } & \multirow[t]{2}{*}{ Rata-rata } \\
\hline & 10 & 20 & 30 & \\
\hline 2000 & 53,33 & 53,41 & 53,44 & 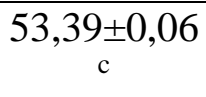 \\
\hline 2500 & 56,86 & 56,36 & 56,27 & $\begin{array}{c}56,49 \pm 0,32 \\
\mathrm{a}\end{array}$ \\
\hline 3000 & 54,54 & 54,90 & 55,05 & $\begin{array}{c}54,83 \pm 0,26 \\
\mathrm{~b}\end{array}$ \\
\hline
\end{tabular}

Rata-rata $\quad 54,91 \pm 1,80^{\text {a }} \quad 54,89 \pm 1,47^{\text {a }} \quad 54,92 \pm 1,42^{\text {a }}$

Keterangan: Huruf yang berbeda di belakang nilai rata-rata pada baris atau kolom yang sama menunjukkan adanya perbedaan yang nyata . Data merupakan rata-rata dari dua kelompok percobaan.

Tabel 6. Nilai rata-rata kadar residu sulfit (ppm) pada perlakuan konsentrasi natrium metabisulfit dan lama perendaman.

\begin{tabular}{ccccc}
\hline Konsentrasi Natrium & \multicolumn{3}{c}{ Lama Perendaman (menit) } & Rata-rata \\
\cline { 2 - 5 } Metabisulfit $(\mathrm{ppm})$ & 10 & 20 & 30 & \\
\hline 2000 & 154,60 & 214,40 & 281,60 & $216,53 \pm 64,03^{\mathrm{c}}$ \\
2500 & 182,40 & 243,20 & 304,00 & $243,20 \pm 60,80^{\mathrm{b}}$ \\
3000 & 208,00 & 291,20 & 329,60 & $276,27 \pm 62,16^{\mathrm{a}}$ \\
\hline Rata-rata & $181,33 \pm 27,22^{\mathrm{c}}$ & $249,60 \pm 38,80^{\mathrm{b}}$ & $305,07 \pm 24,02^{\mathrm{a}}$ &
\end{tabular}

Keterangan: Huruf yang berbeda di belakang nilai rata-rata pada baris atau kolom yang sama menunjukkan adanya perbedaan yang nyata. Data merupakan rata-rata dari dua kelompok percobaan.

\section{Kadar Residu Sulfit}

Hasil analisis keragaman menunjukkan bahwa perlakuan konsentrasi natrium metabisufit dan lama perendaman berpengaruh sangat nyata $(\mathrm{P}<0,01)$, sedangkan interaksi kedua perlakuan berpengaruh tidak nyata $(\mathrm{P}>0,05)$ terhadap kadar residu sulfit (Lampiran 6). Nilai ratarata dari kadar residu sulfit dapat dilihat pada Tabel 6.

Tabel 6 menunjukkan bahwa rata-rata residu sulfit tertinggi diperoleh pada perlakuan konsentrasi 3000 ppm dengan lama perendaman 30 menit. Sedangkan total residu sulfit terkecil diperoleh pada perlakuan konsentrasi 2000 ppm dengan lama perendaman 10 menit. Hal ini menunjukkan bahwa residu sulfit pada bubuk bunga kenikir meningkat seiring penambahan konsentrasi natrium metabisulfit $\left(\mathrm{Na}_{2} \mathrm{~S}_{2} \mathrm{O}_{5}\right)$ dan lama perendamannya. Semakin tinggi konsentrasi dan lama perendaman maka semakin banyak 
kadar sulfit yang mengendap dan meresap pada bunga kenikir. Hasil ini didukung oleh penelitian Suprihatin et al. (2012) tentang pengaruh natrium metabisulfit terhadap warna gelatin kakap merah menunjukkan bahwa penambahan konsentrasi natrium metabisulfit akan mempengaruhi kadar residu sulfit menjadi meningkat. Hasil residu sulfit dari perlakuan konsentrasi 2000 dan 2500 ppm dengan lama perendaman 10 sampai 20 menit masih berada dalam batas yang di izinkan oleh PerKa BPOM No 23 tahun 2013 ( $\leq 300 \mathrm{ppm})$, sedangkan penambahan konsentrasi natrium metabisulfit 2500 ppm dan 3000 ppm dengan lama perendaman 30 menit menunjukkan rata-rata residu sulfit di atas batas maksimum yaitu 304 dan 329 ppm.

\section{KESIMPULAN}

\section{Kesimpulan}

Berdasarkan penelitian yang telah dilakukan maka dapat disimpulkan beberapa hal sebagai berikut :

1. Perlakuan konsentrasi natrium metabisulfit berpengaruh terhadap kadar total karotenoid, tingkat kecerahan $\left(\mathrm{L}^{*}\right)$, tingkat kekuningan $\left(b^{*}\right)$, kadar residu sulfit dan kadar air, namun tidak berpengaruh terhadap tingkat kemerahan $\left(a^{*}\right)$. Perlakuan lama perendaman berpengaruh terhadap kadar residu sulfit tetapi tidak berpengaruh terhadap kadar total karotenoid, tingkat kecerahan $\left(\mathrm{L}^{*}\right)$, tingkat kekuningan $\left(\mathrm{b}^{*}\right)$, tingkat kemerahan $\left(a^{*}\right)$, dan kadar air.

2. Perlakuan perendaman dalam larutan natrium metabisulfit konsentrasi 2500 ppm dan lama perendaman 10 menit, merupakan perlakuan terbaik untuk menghasilkan bubuk bunga kenikir dengan karakteristik kadar total karotenoid sebesar 18,91\%, tingkat kecerahan $\left(\mathrm{L}^{*}\right) 44,19$, tingkat kemerahan $\left(a^{*}\right)$ 63,80, tingkat kekuningan $\left(b^{*}\right)$
56,86 , kadar residu sulfit 182,40 ppm, dan kadar air 11,40\%.

\section{Saran}

Berdasarkan hasil penelitian ini dapat disarankan penelitian lebih lanjut mengenai proses pembuatan bubuk bunga kenikir perlu dilakukan. Salah satunya dengan mempertimbangkan faktor lain seperti suhu perendaman untuk mendapatkan bubuk bunga kenikir dengan kriteria terbaik, serta dilakukannya perlakuan lanjutan seperti ekstraksi dan enkapsulasi agar mendapatkan ekstrak pewarna yang dapat diaplikasikan ke dalam bahan pangan.

\section{DAFTAR PUSTAKA}

Akolo, I.R., dan R. Azis. 2018. Analisis pengaruh natrium metabisulfit $\left(\mathrm{Na}_{2} \mathrm{~S}_{2} \mathrm{O}_{5}\right)$ dan lama penyimpanan terhadap proses browning buah pir menggunakan rancangan faktorial. Jurnal Technopreneur. 5(2): 54-58.

Arini, N., D.W. Respatie dan S. Waluyo. 2015. Pengaruh takaran SP36 terhadap pertumbuhan, hasil dan kadar karotena bunga cosmos sulphureus cav. dan tagetes erecta L. di dataran rendah. Vegetalika. 4(1):1-4.

Aristyanti, N.P.P., N.M. Wartini dan I.B.W. Gunam. 2017. Rendemen dan krakteristik ekstrak pewarna bunga kenikir (Tagetes erecta L.) pada perlakuan jenis pelarut dan lama ekstraksi. Jurnal Rekayasa dan Manajemen Agroindustri. 5(3):13-23.

Ditjen P.O.M. dan Depkes R.I., 1986. Sediaan Galenik. Departemen Kesehatan Republik Indonesia, Jakarta.

Gross, J. 1991. Pigments in Vegetables (Chlorophylls and Carotenoids). Van Nostrand Reinhold, New York. 
Herudiyanto, M., D.M. Sumanti dan R.N. Ahadlyah. 2007. Pengaruh konsentrasi dan lama perendaman dalam larutan natrium metabisulfit $\left(\mathrm{Na}_{2} \mathrm{~S}_{2} \mathrm{O}_{5}\right)$ terhadap karakteristik tepung bawang merah (Allium ascalonicum $\mathrm{L}$ ) varietas sumenep. Jurnal Teknotan. 1(1): 9-12

Khuluq, A. D., S. B. Widjanarko dan E.S. Murtini. 2007. Ekstraksi dan stabilitas betasianin daun darah (Alternanthera dentata) (kajian perbandingan pelarut air:etanol dan suhu ekstraksi). Jurnal Teknologi Pertanian. 8(3): 172-181.

Muchtadi, D. 1989. Evaluasi Nilai Gizi Pangan. Departemen Pendidikan dan Kebudayaan Direktorat Jenderal Pendidikan Tinggi Pusat Antar Universitas Pangan dan Gizi. Institut Pertanian Bogor, Bogor.

Padmaningrum, R.T, dan M.P. Utomo. 2009. Perubahan warna dan kadar $\beta$-karoten dalam tepung ubi jalar (Ipomea batatas, L ) akibat pemutihan. Jurnal Penelitian Siantek. 12(2):153-170.

Prabasini, H., D. Ishartani, dan D. Rahadian. 2013. Kajian sifat kimia dan fisik tepung labu kuning (Curcurbita moschata) dengan perlakuan blanching dan perendaman dalam natrium metabisulfit $\left(\mathrm{Na}_{2} \mathrm{~S}_{2} \mathrm{O}_{5}\right)$. Jurnal Teknosains Pangan. 2(2): 93-102.

Priyanka, D., T. Shalini and V.K. Navneet. 2013. A brief study on marigold (Tagetes Species): A Review. International Research Journal of Pharmacy. 4(1):43-48.

Ranganna, S. 1997. Hanboor of Analysis and Quality Control for Fruits and Vegetable Products. Tata Mac Graw Hill Publication Co, New Delhi. P. 112
Satriyanto, B., S. B. Widjanarko dan Yunianta. 2012. Stabilitas warna ekstrak buah merah (Pandanus conoideus) terhadap pemanasan sebagai sumber potensial pigmen alami. Jurnal Teknologi Pertanian 13(3): 157-168.

Slamet, A. 2010. Pengaruh perlakuan pendahuluan pada pembuatan tepung ganyong (canna edulis) terhadap sifat fisik dan amilografi tepung yang dihasilkan. Agrointek. 4(2):100-103.

Sudarmadji, S., B. Haryono dan Suhardi. 1997. Analisa Bahan Makanan dan Pertanian. Penerbit Liberty, Yogyakarta.

Suprihatin., I.Y.B. Lelana, dan N. Ekantari. 2012. Pengaruh natrium metabisulfit $\left(\mathrm{Na}_{2} \mathrm{~S}_{2} \mathrm{O}_{5}\right)$ terhadap warna gelatin kulit kakap merah. Jurnal Perikanan (J. Fish. Sci.). 15(2): 64-70.

Tan, T.C., L.H. Cheng., R. Bhat., G. Rusul., and A.M. Easa. 2015.Effectiveness of ascorbic acid and sodium metabisulfite as anti-browning agent and antioxidant on green coconut water (Cocos nucifera) subjected to elevated thermal processing. International Food Research Journal. 22(2): 631-637

Vasudevan, P., S. Kashyap and S. Sharma. 1997. Tagetes: A Multipurpose Plant. Bioresource Technol. 6(2): 29-35.

Weaver, C. 1996. The Food Chemistry Laboratory. CRC Press, Boca Raton, New York, London, Tokyo. 